\title{
PENGARUH PEMBELAJARAN BERPOLA PEMBERDAYAAN BERPIKIR MELALUI PERTANYAAN (PBMP) TERHADAP PEMAHAMAN KONSEP DAN KETERAMPILAN METAKOGNITIF MAHASISWA S1 PGSD UNIVERSITAS MATARAM
}

\author{
Anindita SHM Kusuma ${ }^{1 *}$, Khairun Nisa ${ }^{1}$, Zulhan Widya Baskara ${ }^{2}$ \\ ${ }^{1}$ Program Studi Pendidikan Guru Sekolah Dasar, FKIP Universitas Mataram, Indonesia \\ ${ }^{2}$ Program Studi Matematika, FMIPA Universitas Mataram, Indonesia \\ Email: Anindita_fkip@unram.ac.id
}

Article History
Received : April $28^{\text {th }}, 2021$
Revised : May $15^{\text {th }}, 2021$
Accepted : May $22^{\text {th }}, 2021$
Published : May $31^{\text {th }}, 2021$

\begin{abstract}
Abstrak: Pola pembelajaran yang dilakukan belum semuanya memonitor pemahaman konsep dan memberdayakan keterampilan metakognitif mahasiswa. Evaluasi pembelajaran masih mengedepankan hasil penilaian tes tengah dan akhir semester sebagai indikator hasil belajar mahasiswa. Pembelajaran sebagian besar hanya menggunakan makalah dan belum ada bahan diskusi lain dalam pembelajaran seperti lembar kerja mahasiswa yang disusun khusus oleh dosen sesuai dengan materi perkuliahan yang dipelajari. Penelitian ini bertujuan untuk mengetahui pengaruh pembelajaran berpola pemberdayaan berpikir melalui pertanyaan (PBMP) terhadap pemahaman konsep dan keterampilan metakognitif mahasiswa S1 PGSD Universitas Mataram. Jenis penelitian adalah penelitian kuantitatif. Metode penelitian yang digunakan adalah quasi-experimental dengan rancangan The One-group Pretest-Posttest Design. Hasil analisis data pemahaman konsep menggunakan uji-t berpasangan diperoleh signifikansi 0.000 lebih kecil dari alpha $0.05(\mathrm{p}<0.05)$ sehingga hipotesis penelitian diterima. Hasil analisis data keterampilan metakognitif diperoleh signifikansi 0.000 lebih kecil dari alpha 0.05 $(\mathrm{p}<0.05)$ yang berarti bahwa hipotesis penelitian diterima. Kesimpulan dalam penelitian adalah ada pengaruh pembelajaran berpola pemberdayaan berpikir melalui pertanyaan (PBMP) terhadap pemahaman konsep dan keterampilan metakognitif mahasiswa. Berdasarkan rata-rata skor pretest dan posttest baik pemahaman konsep maupun keterampilan metakognitif dapat diketahui bahwa ada peningkatan skor setelah dilakukan pembelajaran dengan pola pemberdayaan berpikir melalui pertanyaan (PBMP). Rekomendasi berdasarkan hasil penelitian terhadap penelitian selanjutnya adalah bahwa akan sangat baik jika pembelajaran menggunakan PBMP dapat diaplikasikan pada banyak matakuliah di prodi PGSD sehingga banyak subyek atau sampel penelitian yang bisa di lihat perkembangan pemahaman konsep dan metakognitifnya pada matakuliah yang berbeda. Penelitian selanjutnya disarankan menggunakan rancangan yang menggunakan kelas kontrol sebagai pembanding hasil kelas yang diberikan perlakuan PBMP.
\end{abstract}

Kata Kunci: Pemberdayaan Berpikir Melalui Pertanyaan, PBMP, Pemahaman Konsep, Keterampilan Metakognitif.

\section{PENDAHULUAN}

Memahami konsep materi dalam pembelajaran merupakan hal yang mutlak harus dikuasai oleh siswa dalam proses belajarnya karena dengan memahami konsep terlebih dahulu maka pebelajar memiliki bekal dasar yang baik untuk mencapai kemampuan dasar yang lain seperti penalaran, komunikasi, koneksi dan pemecahan masalah. Pemahaman konsep adalah pemahaman akan suatu materi yang tidak hanya pada tingkat mengingat saja tetapi harus mampu mengungkapkan kembali dalam bentuk lain tanpa mengubah makna yang terkandung pada konsep tersebut (Purwanto, 2008 dalam Mitasari \& Prasetyo, 2016). Individu dengan pemahaman konsep yang baik telah memiliki prior knowledge yang baik, sehingga ketika dihadapkan pada pengetahuan lain maka individu tersebut akan mampu mengakomodasinya menjadi pengetahuan yang baru. Proses akomodasi pengetahuan baru memerlukan aktivitas metakognisi. Putri, dkk (2013) menjelaskan bahwa meningkatnya pemahaman konsep peserta didik merupakan implikasi dari meningkatnya 
keterampilan metakognitif dan kemampuan berpikir peserta didik.

Metakognisi merupakan kemampuan untuk menyadari, mengetahui, proses kognisi yang terjadi pada diri sendiri dan merupakan kemampuan untuk mengarahkan proses kognisi yang terjadi pada diri sendiri. Metakognisi menurut Livingston (1997 dalam Kusuma, 2014) mengacu pada berpikir tingkat tinggi yang merupakan proses kognitif yang dilibatkan secara aktif selama proses belajar. Keterampilan metakognitif merupakan keterampilan berpikir tingkat tinggi tentang bagaimana cara berpikir yang melibatkan proses kognitif. Komponen dalam keterampilan metakognitif meliputi Planning, Monitoring, Evaluating dan Revising (Schraw \& Dennison, 1994; Thomas, et.al, 2008). Individu dengan metakognitif yang baik akan mampu untuk melakukan perencanaan, pemantauan, dan evaluasi diri dengan baik serta mengontrol proses berpikir yang sedang berlangsung pada diri sendiri. Hal ini tentunya juga mempengaruhi kemampuan mahasiswa dalam kaitannya dengan proses memahami konsep materi yang sedang dipelajari. Semakin sering mahasiswa sadar akan proses berpikir mereka saat mereka belajar, maka mereka akan semakin dapat mengontrol tujuan, fokus belajar dan kemampuan berpikir kritisnya. Chinedu \& Kamin (2015) menyatakan siswa yang dilatih untuk berpikir kritis menunjukkan dampak positif dalam kemajuan pendidikan mereka.

Proses metakognisi ini memainkan peran penting dalam pembelajaran. Metakognisi juga mencakup pengetahuan tentang strategi kognitif dan pengaturan strategi kognitif yang digunakan dalam pembelajaran. Ini memerlukan kesadaran dan pengetahuan tentang kognisi seseorang dan kemampuan untuk merefleksikan kinerja atau pengalaman belajar seseorang. Salah satu komponen tertentu dari metakognisi adalah pengetahuan diri: kesadaran akurat tentang kekuatan dan kelemahan seseorang dan keyakinan motivasi yang terkait dengan pembelajaran (Pintrich, 2002). Ketika diberi kesempatan untuk merefleksikan proses pembelajaran mereka, pebelajar dapat mengatur dan mengelola informasi baru dengan lebih baik dan mengenali strategi pembelajaran apa yang memfasilitasi pemahaman. Kemampuan inilah yang membedakan pakar dengan pebelajar pemula. Selain itu, tindakan refleksi mengubah pengalaman menjadi pembelajaran, dan memungkinkan peserta didik untuk menerapkan pengalaman mereka dalam konteks baru. Pintrich
(2002) menjelaskan bahwa pebelajar dapat mengetahui tentang berbagai strategi untuk membaca buku teks serta strategi untuk memantau dan memeriksa pemahaman mereka saat mereka membaca. Pebelajar juga mengaktifkan pengetahuan yang relevan tentang kekuatan dan kelemahan mereka sendiri yang berkaitan dengan tugas serta motivasi mereka untuk menyelesaikan tugas.

Hasil observasi diketahui bahwa pembelajaran sebagian besar menggunakan makalah sebagai bahan diskusi presentasi. Masih belum nampak adanya bahan diskusi lain dalam pembelajaran misalnya lembar kerja mahasiswa yang disusun khusus oleh dosen sesuai dengan materi perkuliahan yang dipelajari. Pembelajaran yang telah dilakukan belum semuanya memonitor pemahaman konsep dan memberdayakan keterampilan metakognitif mahasiswa. Hal ini salah satunya ditandai dengan evaluasi pembelajaran masih mengedepankan hasil penilaian tes tengah dan akhir semester sebagai indikator hasil belajar mahasiswa. Padahal selain harus memantapkan pemahaman konsep mahasiswanya, diharapkan pendidik mampu mengembangkan metakognitif, agar mahasiswa dapat memantau perkembangan kognitifnya untuk dapat mengetahui kekurangan dan melakukan perbaikan untuk mencapai kemampuan kognitif yang lebih baik. Misalnya, satu temuan kognitif menunjukkan pentingnya mahasiswa menjadi lebih berpengetahuan tentang bagaimana mereka belajar dan bertanggung jawab atas pembelajaran mereka sendiri. Ini melibatkan pengenalan pemahaman konsep dan pengenalan kapan lebih banyak informasi dibutuhkan. Hasil observasi tersebut sejalan dengan pendapat Corebima (2009) yang mneyatakan bahwa pemberdayaan penalaran hampir tidak pernah atau sangat jarang diperhatikan dan dilaksanakan di setiap gerak pembelajaran di Indonesia. Fenomena terkait belum diberdayakannya keterampilan berpikir tingkat tinggi, khususnya keterampilan metakognisi.

Berdasarkan penjelasan tersebut, salah satu pembelajaran yang dapat digunakan untuk memberdayakan kemampuan metakognitif sekaligus pemahaman konsep mahasiswa adalah pembelajaran yang menerapkan pemberdayaan berpikir melalui pertanyaan (PBMP) atau TEQ (Thinking Enpovement by Questioning). Corebima (2008) menjelaskan bahwa pelaksanaan PBMP dilakukan dengan berpedoman pada lembar kerja siswa. Struktur 
umum lembar siswa tersebut adalah: Sediakan, Lakukan, Ringkasan (Pikirkan), Evaluasi dan Arahan. "Lakukan" meliputi kegiatan, penulisan hasil pengamatan, dan renungkan. Bagian yang paling penting dari struktur tersebut agar lembar siswa itu memiliki pola PBMP adalah "Renungkan" dan "Pikirkan". Struktur lembar siswa seperti tersebut dirancang untuk kegiatan pembelajaran yang didukung kerja kelompok dan kerja demonstratif. Pada kegiatan pembelajaran yang tidak didukung kerja kelompok maupun kerja demonstratif, struktur lembar PBMP adalah Pendahuluan, Sediakan, Lakukan, Ringkasan (Pikirkan), Evaluasi dan Arahan.

Menurut Corebima (2001), pola PBMP (TEQ) memang merupakan salah satu cara yang sangat efisien dalam membudayakan penalaran siswa. Ishaq (2015) berdasarkan hasil penelitian yang telah dilakukannya menyatakan bahwa pembelajaran dengan menggunakan strategi PBMP dapat melatihkan keterampilan berfikir siswa. Sejalan dengan hal tersebut, Jamaluddin (2009) menyatakan bahwa siswa-siswa berkemampuan akademik rendah yang belajar dengan strategi PBMP-TPS mampu mencapai keterampilan metakognitif lebih tinggi dari siswa berkemampuan akademik tinggi yang belajar dengan strategi pembelajaran yang sama. Hal ini berarti bahwa strategi pembelajaran PBMP-TPS memberikan pengaruh yang kuat dalam mengembangkan keterampilan metakognitif siswa berkemampuan rendah. Berdasarkan hal tersebut, maka penelitian yang bertujuan untuk mengetahui pengaruh pembelajaran berpola pemberdayaan berpikir melalui pertanyaan (PBMP) terhadap pemahaman konsep dan keterampilan metakognitif mahasiswa S1 PGSD Universitas Mataram, perlu dilakukan.

\section{METODE}

Jenis penelitian adalah penelitian kuantitatif. Metode penelitian yang digunakan adalah quasi-experimental dengan rancangan The One-group Pretest-Posttest Design (Shadish, et.al, 2002). Pada rancangan penelitian yang digunakan, mahasiswa diberikan pretest terlebih dahulu sebelum pembelajaran kemudian selama pembelaharan di ajarkan menggunakan strategi PBMP dan diakhir perkuliahan diberikan posttest. Subyek penelitian adalah kelas 4B Sore Program Studi PGSD Tahun 2019/2020. Secara skematis rancangan penelitian ini adalah sebagai berikut,

\begin{tabular}{lll}
\hline$O_{1}$ & $\mathrm{X}$ & $O_{2}$ \\
\hline
\end{tabular}

(Shadish, et.al, 2002)

Variabel bebas dalam penelitian ini adalah pemberdayaan berpikir melalui pertanyaan (PBMP) dan variabel terikat dalam penelitian ini adalah pemahaman konsep dan kemampuan metakognitif yang keduanya diukur menggunakan tes. Instrumen test untuk mengukur keterampilan metakognitif terintegrasi ke dalam achievement test pemahaman konsep.

\section{HASIL DAN PEMBAHASAN}

\section{Hasil Penelitian}

Penelitian ini dilakukan pada mahasiswa kelas 4B Sore Program Studi PGSD Tahun Pelajaran 2019/2020. Data yang diperoleh dari penelitian ini berupa, skor pemahaman konsep dan keterampilan metakognitif. Hasil penelitian dapat dideskripsikan secara berurutan yakni: (1) skor pemahaman konsep yang diukur sebelum pembelajaran (pretest) dan sesudah pembelajaran (posttest); (2) skor keterampilan metakognitif yang juga diukur sebelum pembelajaran (pretest) dan sesudah pembelajaran (posttest). Perubahan rata-rata skor pemahaman konsep sebelum pembelajaran (pretest) dan setelah pembelajaran (posttest) dapat dilihat pada Gambar 1. Berdasarkan rata-rata skor pretest dan posttest pemahaman konsep dapat diketahui bahwa ada peningkatan skor setelah dilakukan pembelajaran dengan pola pemberdayaan berpikir melalui pertanyaan (PBMP). 


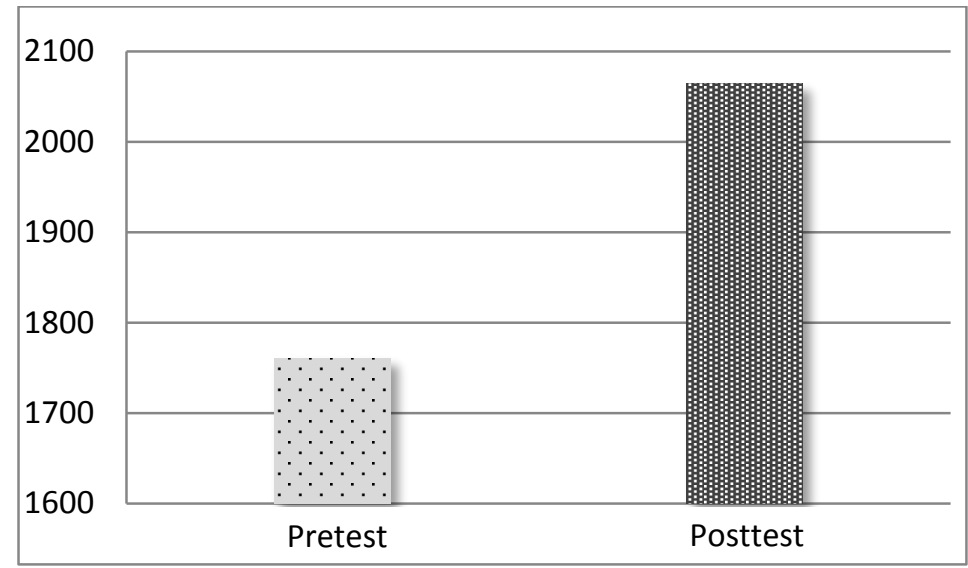

Gambar 1. Rata-rata skor Pretest dan Posttest Pemahaman Konsep

Perubahan rata-rata skor keterampilan metakognitif sebelum pembelajaran (pretest) dan setelah pembelajaran (posttest) dapat dilihat pada Gambar 2 berikut.

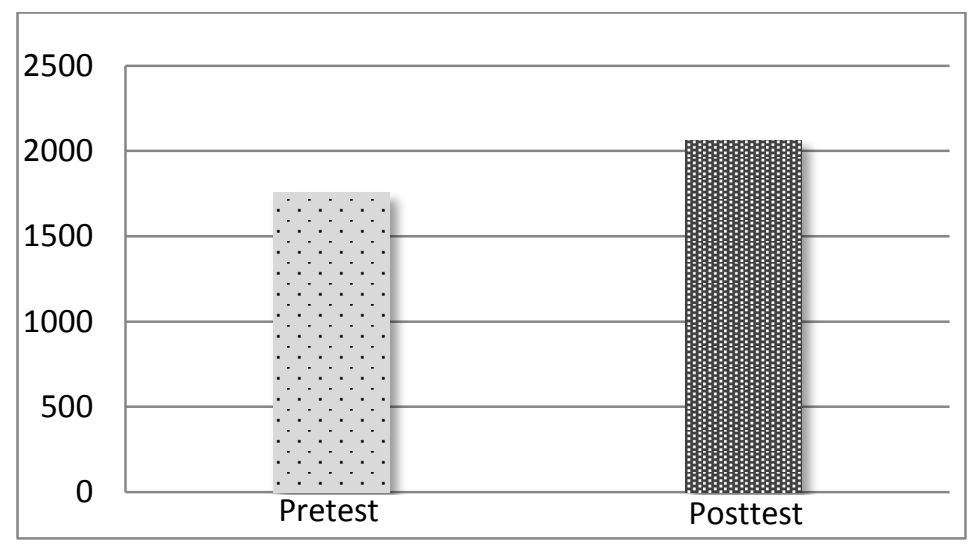

Gambar 2. Rata-rata skor Pretest dan Posttest Keterampilan Metakognitif

Berdasarkan rata-rata skor pretest dan posttest pemahaman konsep dapat diketahui bahwa ada peningkatan skor setelah dilakukan pembelajaran dengan pola pemberdayaan berpikir melalui pertanyaan (PBMP).

Untuk menjawab hipotesis penelitian maka dilakukan uji statistik dengan membandingkan dua rerata (rerata pretest dan rerata posttest).
Sebelum di lakukan uji hipotesis maka terlebih dahulu data di uji homogenitas dan normalitas data. Uji homogenitas menggunakan Uji Levene's Test of Equality of Error Variances dan uji normalitas menggunakan Uji One-Sample Kolmogorov Smirnov. Ringkasan uji homogenitas data dapat dilihat pada Tabel 1.

Tabel 1. Ringkasan Hasil Uji Homogenitas Data.

\begin{tabular}{|l|c|c|c|c|}
\hline & Levene Statistic & df1 & df2 & Sig. \\
\hline PEMAHAMANKONSEP & .006 & 1 & 60 & .937 \\
KETMETAKOGNITIF & .010 & 1 & 60 & .921 \\
\hline
\end{tabular}

Berdasarkan tabel 1 dapat diketahui bahwa signifikansi data pemahaman konsep adalah $0.937>0.05$ sehingga dapat disimpulkan bahwa data pemahaman konsep memiliki varian homogen. Data keterampilan metakognitif memiliki nilai signifikansi sebesar $0.921>0.05$ sehingga dapat disimpulkan bahwa data ketermapilan metakognitif memiliki varian homogen. Ringkasan uji normalitas data dapat dilihat pada tabel 2 berikut. 
Tabel 2. Ringkasan uji normalitas data.

\begin{tabular}{|ll|c|c|}
\hline & & PEMAHAMANKONSEP & KETMETAKOGNITIF \\
\hline $\mathrm{N}$ & & 62 & 62 \\
Normal Parameters $\mathrm{a}, \mathrm{b}$ & Mean & 61.6774 & 58.3871 \\
& Std. Deviation & 13.38555 & 13.20129 \\
& Absolute & .069 & .113 \\
Most Extreme Differences & Positive & .067 & .064 \\
& Negative & -.069 & -.113 \\
Kolmogorov-Smirnov Z & & .542 & .891 \\
Asymp. Sig. (2-tailed) & & .930 & .405 \\
\hline
\end{tabular}

Berdasarkan tabel 2 dapat diketahui bahwa signifikansi data pemahaman konsep adalah $0.930>0.05$ sehingga dapat disimpulkan bahwa data pemahaman konsep berdistribusi normal. Data keterampilan metakognitif memiliki nilai signifikansi sebesar $0.405>0.05$ sehingga dapat disimpulkan bahwa data keterampilan metakognitif berdistribusi normal.

Karena varian semua data homogen dan berdistribusi normal maka uji hipotesis dilanjutkan menggunakan statistika paramaterik uji-t, yakni uji-t berpasangan (Paired-samples $t$ test). Ringkasan hasil uji-t berpasangan (perbandingan dua rerata antara skor pretest dan posttest) pemahaman konsep mahasiswa dapat dilihat pada tabel 3 .

Berdasarkan hasil uji-t berpasangan diperoleh signifikansi 0.000 lebih kecil dari alpha 0.05 ( $\mathrm{p}<0.05)$. Hal ini berarti bahwa Ho yang menyatakan bahwa "tidak ada pengaruh pembelajaran berpola pemberdayaan berpikir melalui pertanyaan (PBMP) terhadap pemahaman konsep mahasiswa" ditolak dan hipotesis penelitian yang menyatakan "ada pengaruh pembelajaran berpola pemberdayaan berpikir melalui pertanyaan (PBMP) terhadap pemahaman konsep mahasiswa" diterima.

Tabel 3. Ringkasan Hasil uji-t pemahaman konsep mahasiswa.

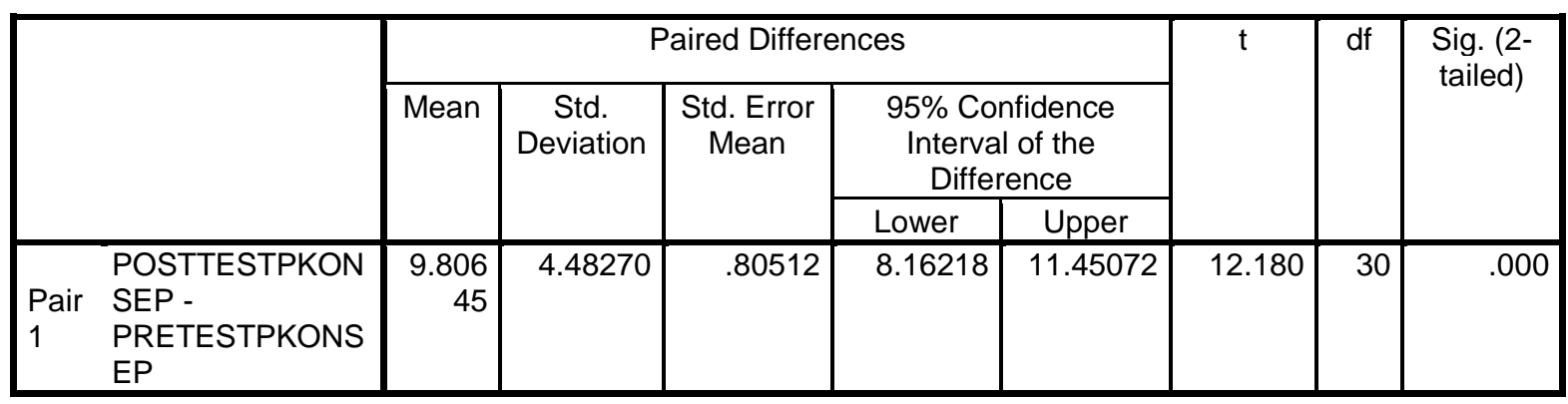

Ringkasan hasil uji-t berpasangan (perbandingan dua rerata antara skor pretest dan posttest) keterampilan metakognitif mahasiswa dapat dilihat pada tabel 4 berikut,

Tabel 4. Ringkasan Hasil uji-t keterampilan metakognitif mahasiswa.

\begin{tabular}{|c|c|c|c|c|c|c|c|c|}
\hline & \multicolumn{5}{|c|}{ Paired Differences } & \multirow[t]{3}{*}{$\mathrm{t}$} & \multirow[t]{3}{*}{$\mathrm{df}$} & \multirow{3}{*}{$\begin{array}{l}\text { Sig. (2- } \\
\text { tailed) }\end{array}$} \\
\hline & \multirow[t]{2}{*}{ Mean } & \multirow[t]{2}{*}{$\begin{array}{c}\text { Std. } \\
\text { Deviation }\end{array}$} & \multirow[t]{2}{*}{$\begin{array}{l}\text { Std. Error } \\
\text { Mean }\end{array}$} & \multicolumn{2}{|c|}{$\begin{array}{l}95 \% \text { Confidence } \\
\text { Interval of the } \\
\text { Difference }\end{array}$} & & & \\
\hline & & & & Lower & Upper & & & \\
\hline $\begin{array}{ll}\text { Pair } & \text { POSTTESTMETA } \\
1 & \text { - PRETESTMETA }\end{array}$ & $\begin{array}{r}11.483 \\
87\end{array}$ & 5.86442 & 1.05328 & 9.33279 & 13.63496 & 10.903 & 30 & .000 \\
\hline
\end{tabular}


Berdasarkan hasil uji-t berpasangan diperoleh signifikansi 0.000 lebih kecil dari alpha 0.05 ( $\mathrm{p}<0.05$ ). Hal ini berarti bahwa Ho yang menyatakan bahwa "tidak ada pengaruh pembelajaran berpola pemberdayaan berpikir melalui pertanyaan (PBMP) terhadap keterampilan metakognitif mahasiswa" ditolak dan hipotesis penelitian yang menyatakan "ada pengaruh pembelajaran berpola pemberdayaan berpikir melalui pertanyaan (PBMP) terhadap keterampilan metakognitif mahasiswa" diterima.

\section{Pembahasan}

Berdasarkan analisis data hasil penelitian menunjukkan bahwa pembelajaran dengan pola pemberdayaan berpikir melalui pertanyaan (PBMP) berpengaruh terhadap pemahaman konsep mahasiswa. Hasil analisis deskriptif ratarata pretest dan posttest mahasiswa dapat diketahui bahwa hasil rata-rata posttest lebih tinggi daripada rata-rata pretest. Corebima (2008) menjelaskan bahwa pembelajaran berpola PBMP mampu memberdayakan siswa untuk menjawab pertanyaan-pertanyaan yang tersusun secara sistematis. Pembelajaran berpola PBMP tidak berlangsung secara informatif, seluruhnya berupa kalimat tanya dan kalimat perintah. Kalimat perintah antara lain digunakan pada bagian cara kerja ataupun bagian lain jika diperlukan. Pola pembelajaran tersebut mampu memicu pebelajar untuk berpikir sehingga apabila pola PBMP diterapkan secara terus-menerus diyakini mampu meningkatkan kemampuan berpikir dan pebelajar mampu mengatur proses berpikir mereka. Sehingga akan sangat baik jika pembelajaran menggunakan PBMP dapat diaplikasikan pada banyak matakuliah di prodi PGSD sehingga banyak subyek atau sampel penelitian yang bisa di lihat perkembangan pemahaman konsep dan metakognitifnya pada matakuliah yang berbeda.

Pada pembelajaran yang telah dilakukan menggunakan struktur lembar kerja PBMP yang meliputi Pendahuluan, Sediakan, Lakukan, Ringkasan (Pikirkan), Evaluasi dan Arahan. Seluruh lembar kerja PBMP berisi pertanyaanpertanyaan yang efektif dan sistematis sesuai dengan tujuan penerapan PBMP. Borich (2017) menyatakan bahwa pertanyaan yang efektif adalah pertanyaan di mana siswa secara aktif menyusun tanggapan dan karenanya terlibat dalam proses pembelajaran. Selain efektif, pertanyaan pada lembar kerja PBMP juga disusun mulai dari konsep besar ke konsep kecil atau bentuk pertanyaan tingkat rendah sampai ke pertanyaan tingkat tinggi.

Pertanyaan tingkat tinggi dan rendah, keduanya berperan penting dalam mengembangkan keahlian berpikir. Pertanyaan tingkat rendah digunakan sebagai starting point untuk menetapkan pengetahuan sebelumnya dan fakta-fakta dasar. Sedangkan pertanyaan tingkat tinggi bertujuan membantu siswa untuk berpikir lebih analitis dan kreatif, dan untuk menyusun pemahaman yang lebih baik tentang sesuatu (Wilson, et al., 1992 dalam Kusuma, 2014).

Corebima (2001) menyatakan bahwa pada bagian yang paling penting dari struktur tersebut agar lembar siswa itu memiliki pola PBMP adalah "Renungkan" dan "Pikirkan". Renungkan merupakan bagian dari "lakukan" yang terdapat pada subbagian lembar kerja PMBP. Bagian yang disebut "Renungkan" berisi kaitan antara konsep dan subkonsep dengan aneka hal lain dalam masyarakat, termasuk didalamnya merupakan perluasan konsep dan subkonsep. Berdasarkan hal tersebut sangatlah jelas bahwa pembelajaran menggunakan PBMP sangat membantu dalam memberdayakan pemahaman konsep mahasiswa.

Selanjutnya hasil analisis data keterampilan metakognitif menunjukkan bahwa pembelajaran dengan pola pemberdayaan berpikir melalui pertanyaan (PBMP) berpengaruh terhadap keterampilan metakognitif mahasiswa. Hasil analisis rata-rata pretest dan posttest keterampilan metakognitif mahasiswa dapat diketahui bahwa hasil rata-rata posttest lebih tinggi daripada rata-rata pretest.

Sebagaimana yang telah dijelaskan bahwa pembelajaran menggunakan PBMP fokusnya adalah pertanyaan-pertanyaan yang tertuang dalam lembar kerja PBMP. Crown (1989) menjelaskan bahwa pembelajaran dengan menggunakan pertanyaan-pertanyaan untuk meningkatkan kemampuan berpikir peserta didik sesuai dengan pembelajaran sciene "the way student learn", yaitu membantu peserta didik berfikir dan merumuskan masalah atau pertanyaan. Pemikiran kritis dapat dikembangkan melalui aktifitas yang tepat semacam pengajuan pertanyaan atau pendekatan inkuiri (dalam Zubaidah 2005).

Lebih lanjut, Rahayu, et al (2017) menjelaskan bahwa pembelajaran dengan metode PBMP sejalan dengan aktifitas metakognitif. Pebelajar diminta menemukan jawaban atas pertanyaan-pertanyaan yang ada pada lembar kerja tersebut secara mandiri. Dalam hal ini, tentunya pebelajar harus mengatur dan 
merencanakan sendiri strategi belajarnya sehingga ia dapat mempelajari dan menyelesaikan lembar kerja PBMP tersebut sebelum didiskusikan di kelas.

Pada pembelajaran yang telah dilakukan, untuk menyelesaikan lembar kerja PBMP tersebut, mahasiswa mencari informasi, membangun pengetahuan serta menuliskan apa yang ditemukan dan dipikirkan selama menyelesaikan lembar kerja. Kegiatan inilah yang ternyata sangat membantu siswa dalam melatih metakognitifnya. Hal ini disebabkan dengan melihat kembali proses berpikirnya melalui tulisan yang dibuatnya sangat membantu mahasiswa untuk melihat bermacam alternatif pendekatan dalam menyelesaikan masalah.

Sejalan dengan pernyataan tersebut, Baker \& Brown (1984) menjelaskan bahwa metakognisi terdiri dari dua bagian keterampilan yang terkait. Pertama, pebelajar harus memahami keterampilan, strategi, dan sumber daya apa yang dibutuhkan mengerjakan suatu tugas. Termasuk dalam bagian ini adalah mencari ide pokok, melatih menyusun informasi, membentuk asosiasi, menggunakan teknik memori, menyusun materi, mencatat atau menggarisbawahi. Kedua, pebelajar harus tahu bagaimana dan kapan menggunakan keterampilan dan strategi ini untuk memastikan tugas diselesaikan dengan baik dan tepat waktu. Kegiatan pemantauan ini termasuk memeriksa tingkat pemahaman, memprediksi hasil, mengevaluasi efektivitas upaya, merencanakan kegiatan, memutuskan bagaimana menganggarkan waktu, dan merevisi atau beralih ke kegiatan lain untuk mengatasi kesulitan.

Livingston (1997) mengemukakan bahwa jika siswa menyadari bahwa ia tidak bisa menjawab atau ia tidak mengerti materi yang sedang didiskusikan, ia akan menentukan apa yang ia perlukan untuk menyelesaikan tujuan kognitifnya atau pemahaman materinya. Ia mungkin akan memutuskan untuk kembali membaca materi tersebut agar dapat menjawab pertanyaan. Siswa dapat memonitor sendiri perkembangan belajarnya. Selain itu, pertanyaanpertanyaan pada tahap evaluasi merupakan intisari dari materi ajar yang mengarah pada indikator pencapaian kompetensi. Tahap evaluasi ini sejalan dengan aktivitas metakognisi dimana siswa dapat mengevaluasi tujuan kognitifnya sendiri (dalam Kusuma, 2014). Selanjutnya, Grotzer \& Mittlefehldt (2012) mengemukakan bahwa pebelajar yang memiliki metakognitif tinggi lebih baik dalam berperilaku, cenderung berprestasi dan proses pembelajaran mereka juga meningkat. Berdasarkan deskripsi tersebut dapat disimpulkan bahwa jelas pembelajaran menggunakan PBMP sangat membantu dalam memberdayakan metakognitif mahasiswa.

Akan tetapi, karena dalam penelitian, subyek penelitian hanya satu kelas sebagai kelas eksperimen maka hasil penelitian tidak memiliki pembanding. Untuk penelitian selanjutnya, akan sangat baik jika terdapat kelas lain sebagai kontrol atau kelas yang tidak diterapkan pembelajaran menggunakan PBMP sehingga ada perbandingan hasil antara kelas yang diterapkan PBMP dan yang tidak.

\section{KESIMPULAN}

Berdasarkan hasil analisis dan pembahasan data pemahaman konsep, dapat disimpulkan bahwa ada pengaruh pembelajaran berpola pemberdayaan berpikir melalui pertanyaan (PBMP) terhadap pemahaman konsep mahasiswa. Berdasarkan rata-rata skor pretest dan posttest pemahaman konsep dapat diketahui bahwa ada peningkatan skor setelah dilakukan pembelajaran dengan pola pemberdayaan berpikir melalui pertanyaan (PBMP). Hasil analisis data dan pembahasan data keterampilan metakognitif, dapat disimpulkan bahwa ada pengaruh pembelajaran berpola pemberdayaan berpikir melalui pertanyaan (PBMP) terhadap keterampilan metakognitif mahasiswa. Berdasarkan rata-rata skor pretest dan posttest keterampilan metakognitif dapat diketahui bahwa ada peningkatan skor setelah dilakukan pembelajaran dengan pola pemberdayaan berpikir melalui pertanyaan (PBMP). Rekomendasi berdasarkan hasil penelitian terhadap penelitian selanjutnya adalah bahwa akan sangat baik jika pembelajaran menggunakan PBMP dapat diaplikasikan pada banyak matakuliah di prodi PGSD sehingga banyak subyek atau sampel penelitian yang bisa di lihat perkembangan pemahaman konsep dan metakognitifnya pada matakuliah yang berbeda. Penelitian selanjutnya disarankan menggunakan rancangan dengan kelas kontrol sebagai pembanding hasil kelas yang diberikan perlakuan PBMP.

\section{UCAPAN TERIMA KASIH}

Terima kasih kepada mahasiswa kelas 4B sore program studi Pendidikan Guru Sekolah Dasar Tahun 2019/2020 yang sedang menempuh 
matakuliah metode penelitian kuantitatif dan semua pihak yang tidak bisa disebutkan satu persatu yang telah membantu selama penelitian hingga penulisan artikel ini selesai.

\section{REFERENSI}

Baker, L., \& Brown, A. L. (1984). Metacognitive skills and reading. Handbook of reading. New York: Longman.

Chinedu, C.C \& Kamin, Y. (2015). Strategies for Improving Higher Order Thinking Skills In Teaching and Learning Of Design And Technology Education. Journal of Technical Education and Training (JTET), 7 (2).

Corebima, A.D. (2001). Pengembangan Lembar PBMP (TEQ) dalam Pembelajaran IPA Biologi. Makalah pada Pelatihan dan Lokakarya PBMP bagi Para Guru IPABiologi dalam Rangka RUT VII.I 31 Agustus - 1 September 2001 di Biologi FMIPA UM.

Corebima, A.D. (2008). Pemberdayaan Keterampilan Metakognitif pada Pembelajaran IPA, IPA Biologi, dan Biologi dalam Mendukung Perkembangan Kemampuan Berpikir Tinggi pada Siswa SD, SMP, dan SMA. Laporan HPTP 2008.

Corebima, A.D. (2009). Metacognitive Skill Measurment Integrated in Achievement Test. Makalah disajikan pada The Third CosMED di Penang, Malaysia.

Grotzer, T \& Mittlefehldt, S. (2012). Metacognition in Science Education: Trends in Current Research. Contemporary Trends and Issues in Science Education Vol 40 (Editor by Zohar, A \& Dory, Y. J). New York: Springer.

Ishaq, M., Muslimin, I, Soetjipto. (2015). Pengembangan Perangkat Pembelajaran Strategi Pemberdayaan Berpikir Melalui Pertanyaan (PBMP) pada Pokok Bahasan Kalor. Jurnal Pena Sains, 2 (1).

Jamaluddin (2009). Pemberdayaan Berpikir Melalui Pertanyaan dan Strategi Kooperatif Untuk Meningkatkan
Keterampilan Metakognitif Siswa. Jurnal Ilmu Pendidikan, Jilid 16, Nomor 3, Oktober 2009.

Kusuma, A.S.H.M. (2014). Pengaruh Pembelajaran Reading Questioning and Answering (RQA), Think Pair Share (TPS), RQA dipadu TPS dan Perbedaan Gender terhadap Keterampilan Bertanya, Kesadaran Metakognitif, Keterampilan Metakognitif, Pembentukan Karakter, dan Hasil Belajar Biologi Siswa kelas VIII SMP Negeri Kota Malang. Tesis. Tidak Diterbitkan. Malang: Program Pascasarjana Universitas Negeri Malang.

Mitasari, Z \& Prasetyo, N. A. (2016). Penerapan Metode Diskusi-Presentasi Dipadu Analisis Kritis Artikel melalui Lesson Study untuk Meningkatkan Pemahaman Konsep, Kemampuan Berpikir Kritis, dan Komunikasi. Jurnal Bioedukatika, 4 (1).

Pintrich, P. R. (2002). The Role of Metacognitive Knowledge in Learning, Teaching, and Assessing. Theory Into Practice, Vol. 41, No. 4, Revising Bloom's Taxonomy (Autumn, 2002). Oxfordshire: Taylor \& Francis, Ltd.

Putri, N. A., Corebima, A. D \& Mahanal, S. (2013). Pengaruh Strategi Pembelajaran (PBL dan RT) terhadap Keterampilan Metakognitif, Hasil BelajarBiologi, dan Resistensi Siswa Berkemampuan Akademik Rendah Kelas X pada SMA yang Berbeda. Skripsi. Tidak diterbitkan. Malang: Universitas Negeri Malang.

Rahmadani, R., Hala, Y \& Ngitung, R. (2017). Pengaruh Metode Pemberdayaan Berpikir Melalui Pertanyaan (PBMP) terhadap Keterampilan Metakognitif dan Berpikir Kritis serta Hasil Belajar Biologi Peserta Didik SMA. Tesis. Tidak diterbitkan. Makassar: Program Pascasarjana Universitas Negeri Makassar.

Schraw, G \& Dennison, R.S. (1994). Assesing Metacognitive Awareness. Contemporary Educational Psychology, 19.

Shadish, W. R., Cook, T. D., \& Campbell, D. T. (2002). Experimental and quasiexperimental Designs for Generalized 
Causal Inference. Boston: Houghton Mifflin and Company.

Thomas, G., Anderson, D., Nashon, S. (2008). Development of An Instrument Designed to Investigated Elements of Science Students Metacognition, Self-Efficacy and Learning Process: The SEMLI-S. International Journal of Science Education, 30 (13).

Zubaidah, S., Mahanal, S. \& Mulyati, Y. (2005). Penerapan Pola Pembelajaran
Pemberdayaan Berpikir Melalui Pertanyaan (PBMP) dengan Metode TPS pada Mata Pelajaran IPA Untuk Meningkatkan Keaktifan dan Hasil Belajar Siswa Kelas IV Madrasah Ibtidaiyah Jenderal Sudirman (MIJS) Malang. Makalah Disajikan Dalam Seminar Nasional Biologi dan Pembelajarannya, Jurusan Biologi FMIPA Universitas Negeri Malang. Malang 3 Desember 2005. 